\title{
Studies on termite infestation of buildings in Ase, a rural community in the Niger Delta of Nigeria
}

\author{
Adaobi Patricia Ugbomeh ${ }^{*}$ (D) and Abiye ThankGod Diboyesuku
}

\begin{abstract}
Background: Termites (Order Isoptera) are eusocial insects that are of great benefit and economic importance to humans. Despite its benefits and economic attributes to humans, it accounts for serious damage on buildings in Nigeria especially in the rural areas. The aim of this study was to collect preliminary data on termite infestation of the buildings in Ase, a local community in the Niger Delta region of Nigeria. Data was collected by direct observation of termites on the buildings, and a structured questionnaire was presented to respondents in houses with visual signs of infestation. Samples of termites were collected from parts of the houses with mud tubes or nests.

Results: A total of 106 houses were inspected with 35.85\% infested with termites. The termites found were two species of Amitermes, one of Microcerotermes, three of Nasutitermes, two of Neotermes, and one of Odontotermes. Most infested homes (71\%) were graded as moderate, severely damaged, and collapsed revealing a major problem. Percentage infestation of wood services revealed door frames 62.5\% and wall (mud tubes) $87.75 \%$, floor 18.85\%, logs outside the house $56.25 \%$, windows and roof $43.75 \%$, ceiling $18.75 \%$, and bathroom, furniture, and kitchen 6 . 25\%. Respondents were 30-90 years old and did not attribute mud tubes to termite infestation. Seventy-two percent of the buildings were less than 60 years, and preventive measures used by respondents were Solignum and used engine oil. Most of the buildings were severely infested, and a $<2$-year-old house showed visible signs of slight termite infestation.
\end{abstract}

Conclusion: This study clearly demonstrates the level of termite infestation in Ase and the need for better control measures and increased awareness for early detection.

Keywords: Termite, Ase, Niger Delta, Buildings, Microcerotermes, Nasutitermes, Neotermes, Amitermes, Odontotermes

\section{Background}

Termites are eurytopic as they are distributed throughout the temperate, tropical, and subtropical regions of the world, with the highest diversity found in tropical forests (Eggleton, 2000). They have different individuals called castes in their nests (Food and Agriculture Organisation [FAO], 2000). Termites largely feed on cellulose and lignocellulose, and they are known to process 50 $100 \%$ of dead plant and decaying biomass in the tropical areas (Bignell \& Eggleton, 2000). Damages arise as a result of the feeding activity of termite which is aided by

\footnotetext{
* Correspondence: ugbomeh.adaobi@ust.edu.ng

Department of Animal and Environmental Biology, Rivers State University, Nkpolu-Oroworukwo, PMB 5080, Port Harcourt, Nigeria
}

the symbiotic microbes, bacteria, and fungi capable of digesting cellulose (Ohkuma \& Brune, 2011). Termites target structural timber in buildings (roofs, windows, and door frames, etc.) and go even deeper into other things within the building such as furniture, clothing, and books (Tagbor, 2009). There are some common genera that have been associated with destruction and they include Coptotermes, Rhinotermes, Macrotermes, Odontotermes, Reticulitermes, Microcerotermes, Ancistrotermes, Schedorhinotermes, Pseudacanthotermes, and Microtermes (Abdurahman, 2000; Ahmed \& French, 2008; Su, Ban, \& Scheffrahn, 2000). Some countries in Africa are unable to list the losses they have incurred as a result of termite damage, but generally, losses due to 
Table 1 Percentage infestation of termite species found in Ase

\begin{tabular}{ll}
\hline Termite species & Percentage infestation (\%) \\
\hline Amitermes spp. A & 26.32 \\
Amitermes spp. B & 5.26 \\
Microcerotermes spp. & 2.63 \\
Nasutitermes spp. A & 18.42 \\
Nasutitermes spp. B & 34.21 \\
Nasutitermes spp. C & 5.26 \\
Neotermes spp. A & 2.63 \\
Neotermes spp. B & 2.63 \\
Odontotermes spp. & 2.63 \\
\hline
\end{tabular}

termite damage worldwide runs into billions of US dollars (Ye, Jones, \& Ammar, 2004).

Although termites are abundant worldwide, Africa seems to be the richest in the number of termite species both known and identified with about $38 \%$ of recognized termites (United Nations Environment Programme [UNEP], 2000). The species richness is as a result of the friendly climatic conditions in Africa such that the family Termitidae has 664 African species (Ahmed et al., 2011). There are four known subfamilies under this family listed as follows: Apicotermitinae (70 species) (Kanwal, Acharya, Ramesh, \& Reddy, 2011), Termitinae (272) African species (Eggleton, 2000), Macrotermitinae (165 species) (Eggleton, 1999), and Nasutitermitinae (56 species) (Mahaney et al., 1999). The total number of species in the above subfamilies may surpass $90 \%$ of the world's known termite species (Ahmed et al., 2011).

Termite damage to buildings in tropical countries is a serious concern. An estimate of the annual loss caused by termite attacks in Nigeria is currently unavailable due to the difficulty in collecting such information from individual home owners or tenants. However, there has been an increased appreciation of the importance of termite

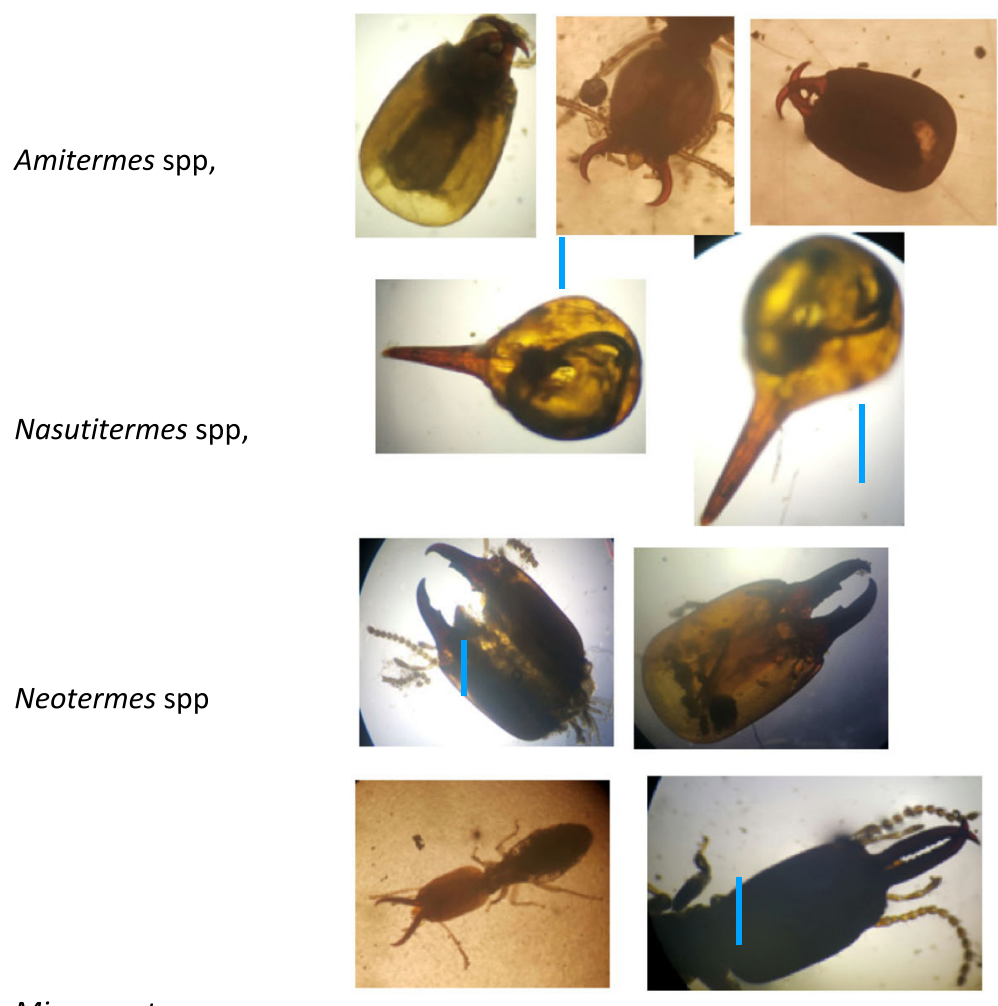

Microcerotermes spp

Odontotermes

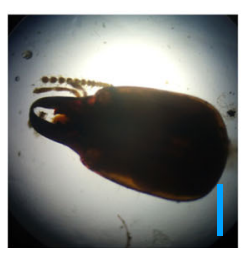

Fig. 1 Heads of some of the termite species found in Ase showing their mandibles_Amitermes spp., Nasutitermes spp., Neotermes spp., Microcerotermes spp., and Odontotermes spp. (Scale bar $=0.73 \mathrm{~mm}$ ) 
Table 2 Site of termite infestation of buildings

\begin{tabular}{|c|c|c|}
\hline Site of termite infestation & Termite species & $\%$ Infestation in infested houses \\
\hline Window frame & $\begin{array}{l}\text { Nasutitermes spp. A, B, and C } \\
\text { Amitermes spp. A and B } \\
\text { Neotermes spp B }\end{array}$ & 43.75 \\
\hline Door frames & $\begin{array}{l}\text { Microcerotermes spp. } \\
\text { Nasutitermes spp. A and B }\end{array}$ & 62.5 \\
\hline Wooden frame of the roof & $\begin{array}{l}\text { Nasutitermes spp. A and B } \\
\text { Neotermes spp. A and B } \\
\text { Amitermes spp. A }\end{array}$ & 43.75 \\
\hline Wood around the houses/fences & $\begin{array}{l}\text { Nasutitermes spp. C and B } \\
\text { Amitermes spp. A }\end{array}$ & 56.25 \\
\hline Wall (mud tubes) in and outside the house & $\begin{array}{l}\text { Nasutitermes spp. } A \text { and } B \\
\text { Amitermes spp. A and B }\end{array}$ & 87.75 \\
\hline Floor and under carpets & $\begin{array}{l}\text { Odontotermes spp. } \\
\text { Neotermes spp. A } \\
\text { Amitermes spp. A }\end{array}$ & 18.75 \\
\hline Ceiling & Nasutitermes spp. A & 18.75 \\
\hline Bathroom walls & $\begin{array}{l}\text { Nasutitermes spp. B } \\
\text { Amitermes spp. A }\end{array}$ & 6.25 \\
\hline Kitchen walls & $\begin{array}{l}\text { Amitermes spp. A } \\
\text { Nasutitermes spp. B }\end{array}$ & 6.25 \\
\hline Furniture & Amitermes spp. A & 6.25 \\
\hline
\end{tabular}

damage to buildings due to regular repairs of wooden services. This has resulted in the use of Solignum and used engine oil as a preventive measure during construction. Due to this and other poor building techniques like lack of flooring with concrete (cement and granite chippings) and tiles, many houses are attacked by termites within a few years of construction. Any form of preventive measure may rapidly deteriorate under the humid tropical conditions (Cassens, Johnson, Feist, \& DeGroot, 1995) making it difficult to control. This treatment added to the cost of replacing damaged furniture, doors, windows, and roofs makes the threat very real. The threat of damage to buildings and the high cost of repairs create a need for constant vigilance on the part of home owners (Wood, 1991). Home owners must therefore be aware of and seek to eliminate the economic loss associated with termite activity. The aim of the study was to collect preliminary data on prevalence of termites and the level of damage due to termite infestation and to conduct a home owner interview in Ase a community in the Niger Delta of Nigeria.

\section{Materials and methods}

Description of study area

Description of the sampling area is as in Aisien, Ugbomeh, and Awharitoma, 2017. Ase town $\left(05.17^{\circ} \mathrm{N} ; 06.18^{\circ}\right.$ E), Delta State in the Niger Delta of Nigeria, lies on the shores of the Ase Creek on the course of the Ase River, which is a tributary of the Forcados River, the western branch of River Niger in the Delta of Southern Nigeria. The climate of the area is tropical, divided into the rainy (February to October) and dry (November to January)

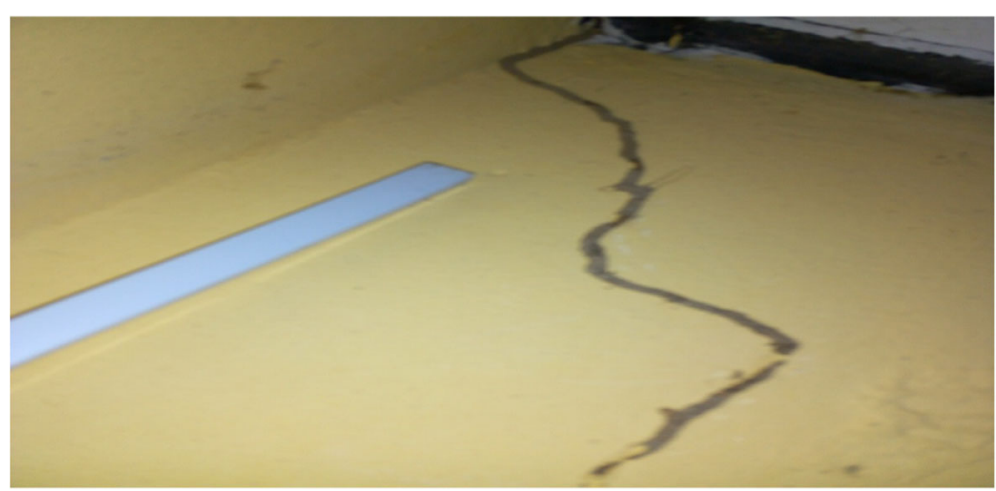

Fig. 2 Mud tubes on the wall (slight infestation) 


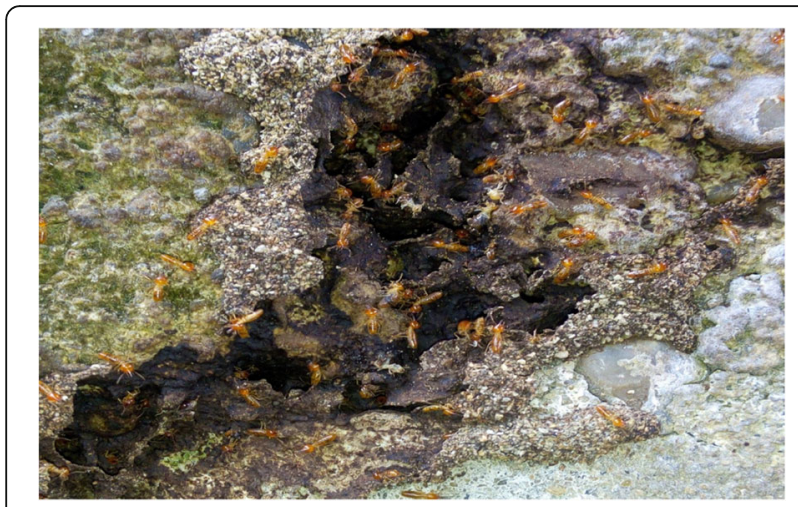

Fig. 3 Showing Nasutitermes on a wall (moderate infestation)

seasons, with intermittent rains in the month of December. During the latter part of the rainy season (September and October), the area gets inundated and aquatic species of both plants and animals are carried ashore with some getting stranded when the water recedes.

\section{Sampling methods and data collection}

The study area was divided into four groups according to the quarters of the Ase community (Umunotu, Ekukeni, Ashaka Ase, and Ogbentido). Sampling was for 4 days in June 2018. A total of 106 houses were randomly assessed for termite infestation based on visual observation of signs such as termite mud tubes on walls, pores in walls, damaged parts such as roofs (wood and grass), windows and door frames, wood in walls, and wooden furniture among others. When a house was found infested, its condition was recorded as in Debelo and Degaga (2014): slightly infested-only mud tubes on walls, roofs, windows and door frames, and mounds (nests) at the base of walls and inside houses without any sign of damage or little damage; moderately infested-woods, walls, windows and door frames, roofs, or woods supporting roofs have been partially eaten, but not completely; severely infested but not collapsed-windows, door frames, some of the woods in walls and/or roofs eaten out completely, and windows and/or door frames cut off or slanted; collapsed-a highly damaged house, which is collapsed or had wood completely eaten out causing the collapse of the supported structure. Pieces of wood in the premises and wooden fences were also inspected for those houses which had wooden fences. An open-ended semi-structured questionnaire was given to 38 homeowners whose homes had termite infestation. Homeowners were interviewed and asked if their house was infested by termites. The contents of the questionnaire were on the age of the house and roof, what type of chemical treatment given during the cause of infestation, and grading of the damage such as mud tubes, mound, and wood damage. Termites were collected with a metal spatula and fixed in $5 \%$ formalin.

\section{Laboratory analysis}

Termites were identified to genus using the shape of the head, shape and serrations of mandible, and antennal elements. Termite specimens collected from different infested houses were examined using a compound microscope and identified using the manual by Muzaffer (1965). Photographs of the infested wood structures and mud tubes were taken using a cannon camera. Statistical analysis includes percentage (\%) prevalence, wood service preference of termite, and distribution of the termites.

\section{Results}

\section{Prevalence of termite infestation}

One hundred and six houses were examined, and 38 (35.85\%) had some form of termite infestation. Five genera and nine species of termite were observed in this study: Amitermes spp. $A$ and B; Microcerotermes spp.; Nasutitermes spp. A, B, and C; Neotermes spp. A and B; and Odontotermes spp. The percentage infestation showed that Nasutitermes spp. B had the highest occurrence with a percentage of $34.21 \%$, while Neotermes spp. A/B, Microcerotermes spp., and Odontotermes spp. had the least prevalence at $2.63 \%$ (Table 1). The Neotermes species (Fig. 1) were different from the African

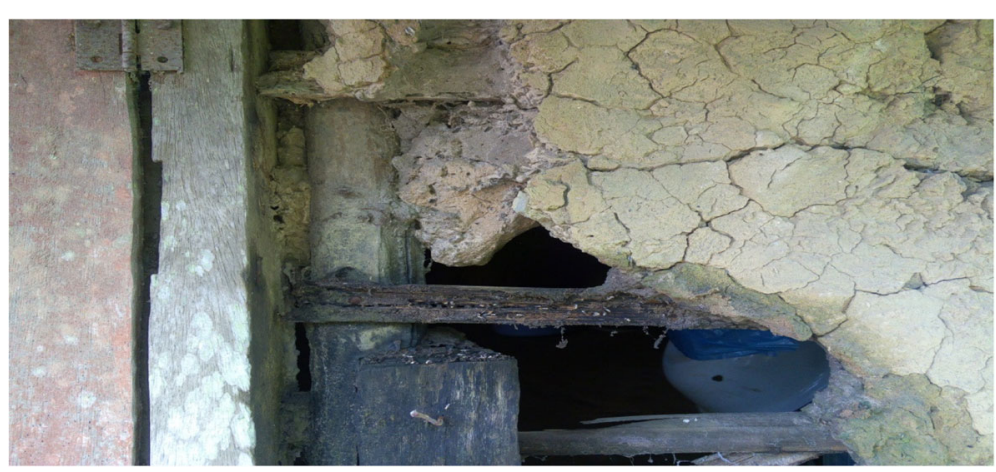

Fig. 4 Amitermes reproductives exposed on a window frame (severe infestation) 


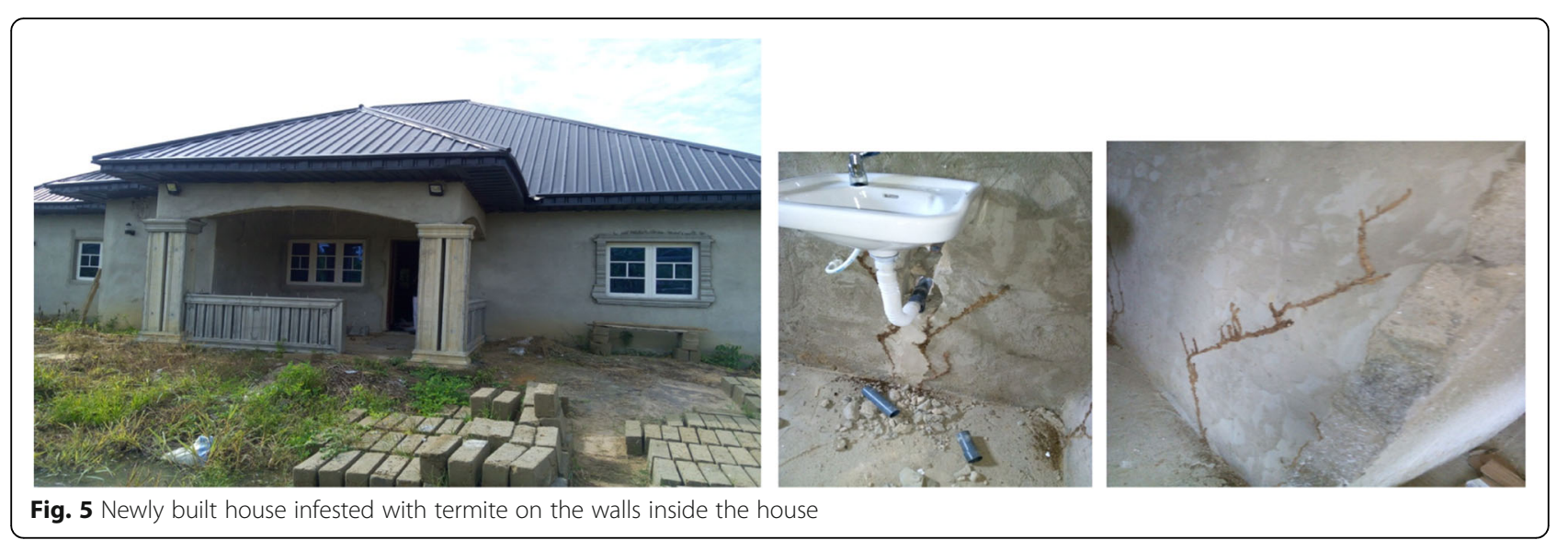

Neotermes $-N$. aburiensis and N. agilis (Onagbola \& Scheffrahn, 2017).

According to one of the respondents, termites appear more abundant during the dry season in Ase (around November to March) as they are found in their trails all around the houses, while in the wet season (April to October) they tend to hide under wooden furniture around buildings causing lots of damage. Walls, door frames, window frames, and the roofs were the sites with the highest termite infestation (Table 2). Termites were found under carpets in homes where they also attacked the furniture, in bathrooms on walls and under sinks in kitchens.

The infested sites (Figs. 2, 3, 4, 5, and 6) revealed 30\% slight infestation, 33\% moderate infestation, $23 \%$ severe infestation, and 15\% collapsed damaged houses.

\section{Socio-economics from the study area}

The socio-economic characteristics of correspondents in Ase (Table 3) showed the mean age, mean family size, age of the house, and roof. Ninety-two percent of the infested houses were more than 5 years old, and all respondents were more than 30 years old. The newest house with termite infestation was less than 2 years
(Fig. 5) with slight termite infestation. All respondents were not aware that the presence of mud tubes meant termite presence or infestation. Twenty percent of respondents with termite infestation had tried different methods to eliminate the termites in severe damage: complete change of woodwork and burning the damaged wood and termite, use of insecticide, and smoking them out.

\section{Discussion and conclusion}

Five genera of termites were identified, Nasutitermes, Amitermes, Neotermites, Microcerotermes, and Odontotermes with Nasutitermes as the most prevalent (57.89\%). A number of factors affect the prevalence of termite species such that it varies from location to location. Ogedegbe and Eloka (2015) found Macrotermes bellicosus as the most prevalent among Coptotermes, Nasutitermes havilandi and N. arboretum, Amitermes evuncifer, Odontotermes, and Microtermes in Edo state. In Indiana, Wang et al. (2009) found five species of Reticulitermes in homes whereas Zhao, Dong, Yu, and Zhang (2012) found Coptotermes formasanus to severely damage homes in China. Materu, Jacob, and Bruno (2013) found Microtermes, Pseudocanthotermes,

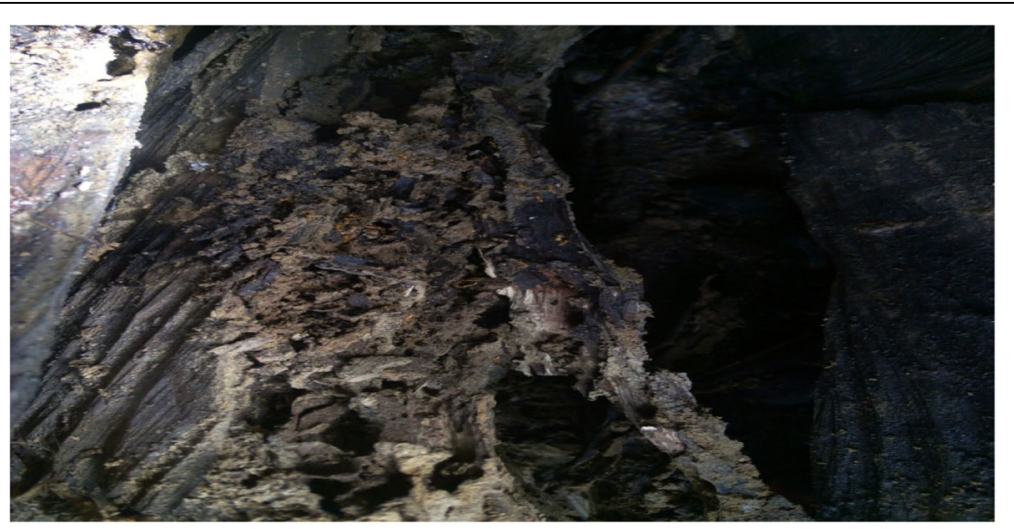

Fig. 6 Collapsed window frame 
Table 3 Socio-economic characteristics of respondents in Ase

\begin{tabular}{|c|c|}
\hline \multicolumn{2}{|c|}{ Age of infected roof and houses of respondent } \\
\hline Age & $\%$ of termite infested houses \\
\hline$<5$ & 8 \\
\hline $5-30$ & 44 \\
\hline $31-60$ & 20 \\
\hline $61-90$ & 24 \\
\hline $91-120$ & 4 \\
\hline \multicolumn{2}{|c|}{ Family size of correspondent } \\
\hline Family size & $\%$ of respondents with family size \\
\hline$<2$ & 12 \\
\hline $2-3$ & 20 \\
\hline $4-5$ & 44 \\
\hline $6-7$ & 20 \\
\hline $8-9$ & 4 \\
\hline \multicolumn{2}{|c|}{ Mean age of correspondent } \\
\hline Mean age & $\%$ of respondents within age class \\
\hline$<30$ & 0 \\
\hline $30-40$ & 26.9 \\
\hline $41-50$ & 11.53 \\
\hline $51-60$ & 15.38 \\
\hline $61-70$ & 11.53 \\
\hline $71-80$ & 15.38 \\
\hline $81-90$ & 19.23 \\
\hline
\end{tabular}

Macrotermes, and Odontotermes to infest coconut nurseries in Tanzania. Debelo and Degaga (2014) recorded 91\% termite infestation in a rural community in Ethiopia due to Macrotermes and Odontotermes. According to the natives in Ase, during the wet season (around February to October), termites tend to be abundant in houses. This is because the environment is humid, wet, and often inundated by water. The termites therefore in search of a drier habitat enter homes and damage the buildings. During the dry season, which is from November to January, they tend to hide under wooden furniture, venturing outside the houses in their trails. They build mud tubes and mounds around the buildings, on the wall, window frames, wood, door frames, floor, roof, ceiling, kitchen, bathroom, and furniture. The presence of two species of Neotermes different from those recorded by Onagbola and Scheffrahn (2017) - N. aburiensis and $N$. agilis from Ghana and Ijare Nigeria, respectively, is significant. Neotermes is a damp wood termite.

Respondents were mostly the elderly with a few middle age. The relatively low infestation (35.85\%) could be due to the modern houses of less than a year which were not infested and also due to constant rebuilding of old houses. However, of the infested houses, more than $71 \%$ had more than slight infestation which should be seen as a problem in the area. Infested houses were 2-100 years old and were without tile flooring. It is important to encourage proper concrete flooring and tiling to reduce the ease of termite infestation as a 2-year-old relatively modern house showed visible signs of termite infestation by Amitermes spp. All respondents claim to have used Solignum and used - engine oil on the wood as a preventive measure but this had not eliminated the termites. This may be due to wrong applications, fake Solignum, or just termite resistance to the effect of the Solignum, and therefore, more studies are required on control measures. In more than $43 \%$ of the infested homes, door and window frames, walls, and roofs were damaged in various degrees. There is the need to create more awareness on early detection of termite presence and effective control measures in the area. The termites appear to overwhelm the people. According to one of the respondents, a newly built house was so severely damaged by termites that the roof collapsed in less than a year. In conclusion, the study has revealed the percentage prevalence of termite infestation in Ase due to five genera of termites Nasutitermes, Amitermes, Microcerotermes, Odontotermes, and Neotermes. It has also revealed the need to educate the natives on the early signs of termite infestation and effective preventive measures.

\section{Acknowledgements \\ We want to sincerely thank Mrs. Omenogo Ugbomeh and Mrs. Nwainyi for their help during the field work and Stephen Igweoji and the Ase youths for their assistance in the collection of samples. We also want to thank Rivers State University for enabling this work.}

Funding

All funding for the research was from the authors.

Availability of data and materials

All data and materials used in this study are available on request.

\section{Authors' contributions}

UAP conceived the study, identified the termites, and wrote the manuscript. DAT carried out field and laboratory work and analyzed the data. All authors read and approved the final manuscript.

\section{Ethics approval and consent to participate}

The authors declare that there was no ethics committee set up on the use of termites for research when the study was carried out. To the best of our knowledge, there are no guidelines either at the institutional or national level needed for ethics approval.

\section{Consent for publication}

Not applicable.

\section{Competing interests}

The authors declare that they have no competing interests.

\section{Publisher's Note}

Springer Nature remains neutral with regard to jurisdictional claims in published maps and institutional affiliations. 
Received: 18 October 2018 Accepted: 3 April 2019

Published online: 29 April 2019

\section{References}

Abdurahman, A. (2000). Termites as structural pests in Ethiopia. In Termite biology and management. Rpt. UNEP/FAO/global IPM Facility workshop 2000, (p. 16). Geneva: UNEP Chemicals.

Ahmed, B. M., \& French, J. R. (2008). An overview of termite control methods in Australia and their link to aspects of termite biology and ecology. Pak. Entomol., 30(2), 101-118.

Ahmed, B. M., Nkunika, P. O. Y., Sileshi, G. W., French, J. R. J., Nyeko, P., \& Jain, S. (2011). Potential impact of climate change on termite distribution in Africa. British Journal of Environment and Climate Change, 1(4), 172-189.

Aisiens, M. S. O., Ugbomeh, A. P., \& Awharitoma, A. O. (2017). Department of Animal Environmental Biology. Parasitic infections of anurans from a freshwater creek community in Delta State, Niger Delta of Nigeria. Helminthologia, 54(2), 132-144.

Bignell, D. E., \& Eggleton, P. (2000). Termites in ecosystems. In T. Abe, D. E. Bignell, \& M. Higashi (Eds.), Termites: Evolution, sociality, symbioses, ecology, (pp. 363388). Dordrecht: Kluwer Academic Publishers.

Cassens, D. L., Johnson, B. R., Feist, W. C., \& DeGroot, R. C. (1995). Selection and use of preservative treated wood, (1st ed., p. 104). Madison. ISBN: 0935018751: Forest Products Society.

Debelo, D. G., \& Degaga, E. G. (2014). Preliminary studies on termite damage on rural houses in the Central Rift Valley of Ethiopia. African Journal of Agricultural Research, 9(39), 2901-2910.

Eggleton, P. (1999). Termite species description rates and the state of termite taxonomy. Insects Sociaux, 46, 1-5.

Eggleton, P. (2000). Global patterns of termite diversity. In T. Abe, D. E. Bignell, \& M. Higashi (Eds.), Termites: Evolution, Sociality, Symbiosis, Ecology. Dordrecht: Kluwer Academic Publishers.

Food and Agriculture Organisation (FAO) (2000). United Nation Environment Programmed.

Kanwal, H. K., Acharya, K., Ramesh, G., \& Reddy, M. S. (2011). Molecular characterization of Morchella species from the Western Himalayan region of India. Current Microbiology, 62(4), 1245-1252.

Mahaney, W. C., Zippin, J., Milner, M. W., Sanmugadas, K., Hancock, R. G. V., Aufreiter, S., \& Kalm, V. (1999). Chemistry, mineralogy and microbiology of termite mound soil eaten by the chimpanzees of the Mahale Mountains, Western Tanzania. Journal of Tropical Ecology, 15(05), 565-588.

Materu, C., Jacob, Y., \& Bruno, N. (2013). Seasonal changes on termite foraging behaviour under different habitats in Rufiji Destrict Tanzania. Journals and Books Hostling, 3(11), 227-233.

Muzaffer, A. (1965). Department of Zoology, University of Panjor Lahore, Parkistan. Bulletin of the American Museum of Natural History, 131(1), 1-144.

Ogedegbe, A. B. O., \& Eloka, E. V. (2015). Soil macrofauna research in ecosystems in Uganda. African Journal of Ecology, 45(2), 2-8.

Ohkuma, M., \& Brune, A. (2011). Diversity, structure and evolution of the termite gut microbial community. In D. E. Bignell, Y. Roisin, \& N. Lo (Eds.), Biology of Termites: A modern synthesis, (pp. 413-438). Dordrecht: Springer.

Onagbola, E. O., \& Scheffrahn, R. H. (2017). African Neotermes: Redescription of imago and soldier caste of N. aburiensis and N. agilis (Isoptera, Kalotermitidae). Zookeys, 683, 25-37.

Su, N. Y., Ban, P. M., \& Scheffrahn, R. H. (2000). Control of Coptotermes havilandi (Isoptera: Rhinotermitidae) with Hexaflumuron baits and a sensor incorporated into a monitoring - baiting programme. Journal of Economic Entomology, 93, 415-421.

Tagbor, A. T. (2009). The anti-termite properties and basic phytochemicals of eight local plants and the chemical characterisation of Thevetia Peruviana (Pers) K., Schum in Ghana PhD Thesis (pp. 12-17).

United Nations Environment Programme [UNEP] (2000). Finding alternatives to persistent organic pollutants (POPS) for termite management. Prepared by members of the UNEP/FAO/global IPM Facility Expert Group on termite biology and management - established in 2000 to support international activities on persistent organic pollutants (POPs) covered by the Stockholm convention.

Wang, C., Zhou, X., Li, S., Schwinghammer, M., Scharf, M., Buczkowski, G., \& Benneth, G. W. (2009). Survey and identification of termites (Isoptera: Rhinotermitidae) from Indiana. Annals of the Entomological Society of America, 102, 1029-1036.
Wood, T. G. (1991). Termites in Ethiopia: the environmental impact of their damage and resultant control measures. Ambio, 20, 136-138.

Ye, Y., Jones, S. C., \& Ammar, E. (2004). Reproductive characteristics of imagos of Reticulitermes flavipes (Isoptera: Rhinotermitidae). Annals of the Entomological Society of America, 102, 889-894.

Zhao, J., Dong, Y., Yu, B., \& Zhang, Z. (2012). Ivermectin dust for the control of Coptotermes formosanus in residential areas. Sociobiology, 59(4), 1365-1373.

\section{Submit your manuscript to a SpringerOpen ${ }^{\circ}$ journal and benefit from:}

- Convenient online submission

- Rigorous peer review

- Open access: articles freely available online

- High visibility within the field

- Retaining the copyright to your article

Submit your next manuscript at $\boldsymbol{\nabla}$ springeropen.com 